\title{
Enterococcus plantarum sp. nov., isolated from plants
}

\author{
Pavel Švec, ${ }^{1}$ Peter Vandamme, ${ }^{2}$ Hana Bryndová, ${ }^{1}$ Pavla Holochová, ${ }^{1}$ \\ Marcel Kosina, ${ }^{1}$ Ivana Mašlaňová ${ }^{1}$ and Ivo Sedláček ${ }^{1}$ \\ ${ }^{1}$ Czech Collection of Microorganisms, Department of Experimental Biology, Faculty of Science, \\ Masaryk University, Tvrdého 14, 60200 Brno, Czech Republic \\ ${ }^{2}$ Laboratory of Bacteriology, Ghent University, K. L. Ledeganckstraat 35, B-9000 Ghent, Belgium
}

Correspondence

Pavel Švec

mpavel@sci.muni.cz
Eight Gram-positive, catalase-negative bacterial strains were isolated during screening of enterococcal populations on plants. rep-PCR fingerprinting using the (GTG) ${ }_{5}$ primer showed that the isolates constituted a single cluster that was separate from all known enterococcal species. 16S rRNA gene sequence phylogenetic analysis of three representative strains showed that the isolates belonged to the genus Enterococcus and that they clustered with the Enterococcus faecalis species group. Sequencing of the genes for the phenylalanyl-tRNA synthase alpha subunit (pheS) and the RNA polymerase alpha subunit $(r p o A)$ also revealed the isolates' separate taxonomic position. Application of whole-cell protein fingerprinting, automated ribotyping and extensive phenotyping demonstrated the genetic and phenotypic homogeneity of the isolates and confirmed their separate position within the $E$. faecalis species group. The isolates represent a novel species of the genus Enterococcus, for which the name Enterococcus plantarum sp. nov. is proposed; the type strain is CCM $7889^{\top}$ (=LMG $\left.26214^{\top}=\mathrm{C} 27^{\top}\right)$.
The genus Enterococcus is phylogenetically placed in the family Enterococcaceae within the order Lactobacillales. The genus currently comprises 35 species (Euzéby, 1997) and occurs in the human and animal gastrointestinal tract, food and the environment. Enterococci are well-known opportunistic pathogens and are important to human medicine as they are a common cause of a variety of infections, including nosocomial infections. In contrast, they play a beneficial role in many dairy and fermented foods and certain strains are used as probiotics (Franz \& Holzapfel, 2004; Švec \& Devriese, 2009). The environmental enterococci are a taxonomically diverse group. Particularly, the enterococci associated with plants represent lesser-known bacterial groups and only a handful of taxonomic studies dealing with enterococci isolated from plants have been published to date. Mundt $(1961,1963)$ who studied the occurrence of enterococci (group D streptococci) on agricultural plants and grasses concluded that they are

Abbreviations: pheS, phenylalanyl-tRNA synthase alpha subunit gene; rpoA, RNA polymerase alpha subunit gene.

The GenBank/EMBL/DDBJ accession numbers for the 16S rRNA gene sequences of strains CCM $7889^{\top}$, CCM 7887 and CCM 7890 are HQ847537-H0847539, respectively. The GenBank/EMBL/DDBJ accession numbers for the pheS and rpoA sequences obtained in this study are HO847540-HO847551 and JF276437-JF276444, respectively.

Four supplementary figures and a supplementary table are available with the online version of this paper. temporary residents and inhabit plants because of the wind and insect activity. Later studies, conducted by Ulrich \& Müller (1998), Müller et al. (2001) and Ott et al. (2001), revealed the occurrence of Enterococcus faecalis, Enterococcus faecium, Enterococcus hirae, Enterococcus mundtii, Enterococcus casseliflavus and Enterococcus sulfureus on plants; however, these works reported a high proportion of enterococcal strains as representing unknown plant-associated species.

Eight bacterial strains were isolated during a project dealing with the enterococcal microflora of plants. The isolates were retrieved from different plants from June to October 2009 (Table 1). Plant samples were obtained from a meadow situated about $600 \mathrm{~m}$ from the village of Lipina in the Olomouc district in the Czech Republic $\left(49^{\circ} 44^{\prime}\right.$ $\left.29.979^{\prime \prime} \mathrm{N} 17^{\circ} 19^{\prime} 24.696^{\prime \prime} \mathrm{E}\right)$. The meadow is surrounded by a mixed forest, is not influenced by farm animals and is exploited only for hay harvesting. Plant specimens were aseptically sampled and initially cultivated in brain-heart infusion broth (BHI; Oxoid) at $37{ }^{\circ} \mathrm{C}$ for $48 \mathrm{~h}$ and subsequently grown on kanamycin aesculin azide agar (KAA; Merck) at $37{ }^{\circ} \mathrm{C}$ for $48 \mathrm{~h}$. Individual colonies of the typical black enterococcal colony morphology were purified on BHI agar and stored at $-70{ }^{\circ} \mathrm{C}$. Reference strains were deposited in the Czech Collection of Microorganisms (CCM; Masaryk University, Brno, Czech Republic; http:// www.sci.muni.cz/ccm/) and in the BCCM/LMG Bacteria Collection (Ghent University, Ghent, Belgium; http://bccm. belspo.be). 
Table 1. Sources and isolation dates of strains

CCM, Czech Collection of Microorganisms, Czech Republic; LMG, BCCM/LMG Bacteria Collection, Belgium.

\begin{tabular}{|llll|}
\hline Strain number & Other strain designations & \multicolumn{1}{c|}{ Source } & Isolation date \\
\hline CCM 7887 & C38 & Aegopodium sp., flower & 24 June 2009 \\
CCM 7888 & G25 & Campanula sp., flower & 12 October 2009 \\
CCM 7889 & C27, LMG 26214 & Aegopodium sp., flower & 24 June 2009 \\
CCM 7890 & D15 & Melampyrum sp., flower & 31 July 2009 \\
P3745 & B4 & Carex sp., flower & 1 June 2009 \\
P3746 & B29, LMG 26212 & Carduus sp., flower & 1 June 2009 \\
P3747 & D27/2, LMG 26213 & Thymus sp., complete plant & 31 July 2009 \\
P3748 & G10/2, LMG 26211 & Leontodon sp., flower & 12 October 2009 \\
\hline
\end{tabular}

Initial genotypic screening was performed using rep-PCR fingerprinting with the $(\mathrm{GTG})_{5}$ primer, which has been evaluated for the identification of species of the genus Enterococcus (Švec et al., 2005). The method was performed as described by Švec et al. (2008). Numerical analysis of the (GTG) ${ }_{5}$-PCR fingerprints was done using BioNumerics version 6.5 (Applied Maths) and resulting fingerprints were compared with those in the in-house CCM database, which contains multiple strains of all hitherto-described species of the genus Enterococcus. Fig. S1 (available in IJSEM Online) shows the $(\mathrm{GTG})_{5}$-PCR fingerprints obtained from the isolates and demonstrates their separation from members of the genus Enterococcus. All eight isolates were placed in a single cluster that was clearly separate from the reference strains. The cluster contained two subclusters that showed differences in bands in the range of 1600-1800 bp.

For $16 \mathrm{~S}$ rRNA gene sequencing, strains CCM 7887, CCM $7889^{\mathrm{T}}$ and CCM 7890 were cultivated on BHI agar at $37{ }^{\circ} \mathrm{C}$ overnight. DNA was extracted by suspending one loop of cells in $500 \mu \mathrm{l}$ sterile deionized water and heating at $80{ }^{\circ} \mathrm{C}$ for $20 \mathrm{~min}$. Subsequently, the crude extracts were centrifuged at 14000 r.p.m. for $1 \mathrm{~min}$ and the supernatant was used directly as a template for PCR. Amplification was performed using the universal primers $16 \mathrm{~S}$ _F1 (5' AGAGTTTGATCCTGGCTCAG-3'; Coenye et al., 1999) and 16S_R1530 (5'-AAGGAGGTGATCCAGCCGCA-3'; Hughes et al., 2000). The PCR programme consisted of: denaturation for $5 \mathrm{~min}$ at $95{ }^{\circ} \mathrm{C}$; three cycles of $30 \mathrm{~s}$ at $95{ }^{\circ} \mathrm{C}, 60 \mathrm{~s}$ at $58{ }^{\circ} \mathrm{C}$ and $60 \mathrm{~s}$ at $72{ }^{\circ} \mathrm{C} ; 30$ cycles of $20 \mathrm{~s}$ at $95{ }^{\circ} \mathrm{C}, 30 \mathrm{~s}$ at $58{ }^{\circ} \mathrm{C}$ and $75 \mathrm{~s}$ at $72{ }^{\circ} \mathrm{C}$; and final extension for $7 \mathrm{~min}$ at $72{ }^{\circ} \mathrm{C}$. The PCR products were subsequently purified using a High Pure PCR product purification kit (Roche Diagnostics). Sequencing was performed by Eurofins MWG Operon (Ebersberg, Germany). Partial 16S rRNA gene sequences were combined into a single consensus sequence using the internet assembler tool CAP3 Sequence Assembly Program (Huang \& Madan, 1999). The sequences obtained and reference sequences downloaded from GenBank were aligned using CLUSTAL w (Thompson et al., 1994) with a gap opening penalty of 15 and a gap extension penalty of 6.66. Evolutionary distances were computed by maximum composite likelihood and a phylogenetic tree was constructed by the neighbour-joining method (Saitou \& Nei, 1987) using MEGA4 (Tamura et al., 2007). The tree topology was evaluated and confirmed by maximum parsimony using Bionumerics version 6.5. Fig. 1 is the resulting consensus tree inferred from 1000 replicates and shows the phylogenetic position of strains CCM 7887, CCM $7889^{\mathrm{T}}$ and CCM 7890 within the genus Enterococcus. All isolates revealed $100 \% 16 \mathrm{~S}$ rRNA gene sequence similarity with each other and were placed within the E. faecalis species group, which contained E. faecalis JCM $5803^{\mathrm{T}}$, Enterococcus caccae $2215-02^{\mathrm{T}}$, Enterococcus haemoperoxidus CCM $4851^{\mathrm{T}}$, Enterococcus moraviensis CCM $4856^{\mathrm{T}}$, Enterococcus silesiacus LMG $23085^{\mathrm{T}}$ and Enterococcus termitis LMG $8895^{\mathrm{T}}$. Global alignment performed by the algorithm of Myers \& Miller (1988) using the EzTaxon web-based tool (Chun et al., 2007) showed that the isolates shared 99.9\% $16 \mathrm{~S}$ rRNA gene sequence similarity with $E$. moraviensis CCM $4856^{\mathrm{T}}$ and $99.8 \% 16 \mathrm{~S}$ rRNA gene sequence similarity with $E$. silesiacus LMG $23085^{\mathrm{T}}$ and E. haemoperoxidus CCM $4851^{\mathrm{T}}$.

Multilocus sequence analysis based on partial sequences for the genes of the phenylalanyl-tRNA synthase alpha subunit (pheS) and the RNA polymerase alpha subunit (rpoA) was performed for all isolates, according to the method described by Naser et al. (2005), who demonstrated that these genes are valuable tools for the delineation of enterococci species. Chromosomal DNA was isolated from overnight cultures grown on BHI agar at $37^{\circ} \mathrm{C}$ and extracted as described above for $16 \mathrm{~S}$ rRNA gene sequence. Primer sequences and PCR amplification conditions were as described by Naser et al. (2005). The amplified pheS and rpoA PCR products were subsequently purified using the High Pure PCR product purification kit (Roche Diagnostics) and the sequencing procedure was performed by Eurofins MWG Operon (Ebersberg, Germany). The pheS and rpoA sequences of the type strains representing the currently validly described Enterococcus spp. were retrieved from the GenBank database. The sequences were aligned in CLUSTAL $\mathrm{W}$ (Thompson et al., 1994) using the gap opening penalty 15 and gap extension penalty 6.66 parameters and the phylogenetic tree was calculated by the neighbour-joining method (Saitou \& Nei, 1987) using MEGA4 (Tamura et al., 2007). The resulting pheS and rpoA dendrograms inferred 


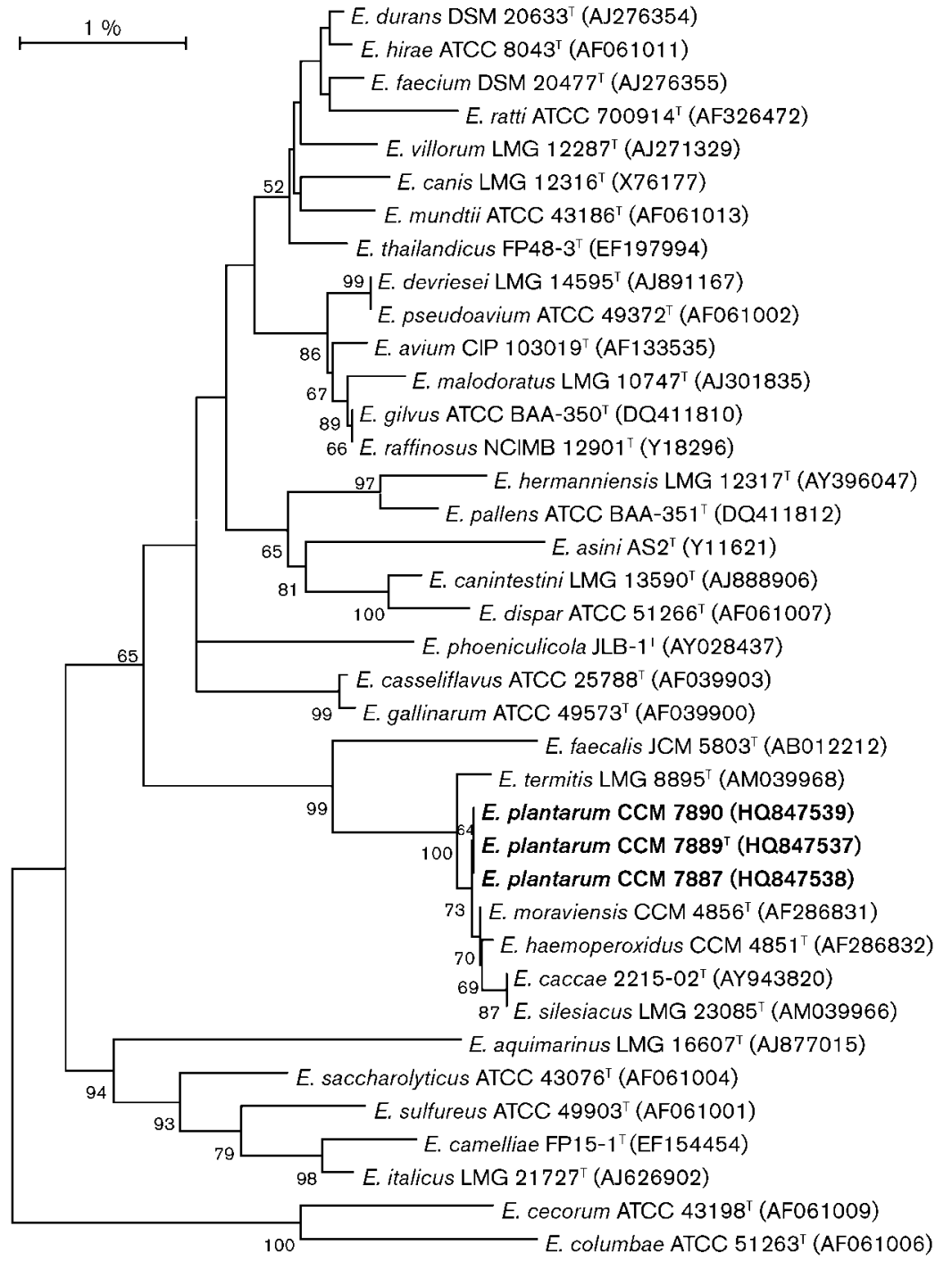

Fig. 1. Neighbour-joining phylogenetic tree based on $16 \mathrm{~S}$ rRNA gene sequences showing the positions of strains CCM $7889^{\top}$, CCM 7887 and CCM 7890 within the genus Enterococcus. Bootstrap values ( $>50 \%$ ) based on 1000 replications are shown at branch nodes. Bar, $1 \%$ sequence divergence. from 1000 replicates (Fig. 2) demonstrated that the isolates formed a homogeneous cluster $(>99.7$ and $>99.8 \%$ pheS and $r p o A$ gene sequence similarities, respectively) that was clearly separate from members of the E. faecalis species group. The isolates showed the highest pheS sequence similarity (88.1\%) with E. haemoperoxidus LMG $19487^{\mathrm{T}}$ and the highest rpoA sequence similarity (97.6\%) with $E$. silesiacus CCM $7319^{\mathrm{T}}$ and E. caccae $7399^{\mathrm{T}}$. Extended pheS and rpoA phylogenetic trees for the isolates and the type strains of all species of the genus Enterococcus are shown in Figs S2 and S3, respectively.

Phenotypic characterization was performed using the API 20 Strep and API $50 \mathrm{CH}$ systems (bioMérieux), STREPTOtest 24 (Pliva-Lachema Diagnostika) and GP2 MicroPlates (Biolog), as well as using conventional growth and physiological tests. Growth characteristics were tested on Columbia agar (Oxoid) supplemented with $5 \%$ sheep blood, BHI agar, KAA agar and Slanetz and Bartley medium (Oxoid). Growth at 10 and $45{ }^{\circ} \mathrm{C}$, with $6.5 \% \mathrm{NaCl}$ and at $\mathrm{pH} 9.6$ was examined in BHI broth for up to 5 days.
Catalase production was tested using an ID Colour Catalase kit (bioMérieux). Lancefield antigens were determined using a Strep kit (Diamondial). Production of gas from glucose was tested according to Sperber \& Swan (1976). Pyrrolidonyl arylamidase and acetoin production were tested using PYRAtest and VPtest, respectively (PLIVA-Lachema Diagnostika). Urease production was tested on Urea Agar Base Christensen (HiMedia). Motility was studied on stabinoculated semi-solid medium [1\% tryptone (Oxoid), $0.4 \%$ nutrient broth (Merck), $0.5 \% \mathrm{NaCl}$ and $0.4 \%$ agar (Sigma-Aldrich)] with cultivation at $37{ }^{\circ} \mathrm{C}$ for $24 \mathrm{~h}$ and then at room temperature for up to 5 days. The results are given in the species description and Table S1. The isolates could be differentiated from members of the E. faecalis species group by the characteristics given in Table 2 .

Whole-cell protein fingerprints have been proved to correlate well with DNA-DNA relatedness (Vandamme et al., 1996) and have been evaluated for the identification of enterococci and the description of novel Enterococcus species in numerous studies (Alves et al., 2004; Facklam 

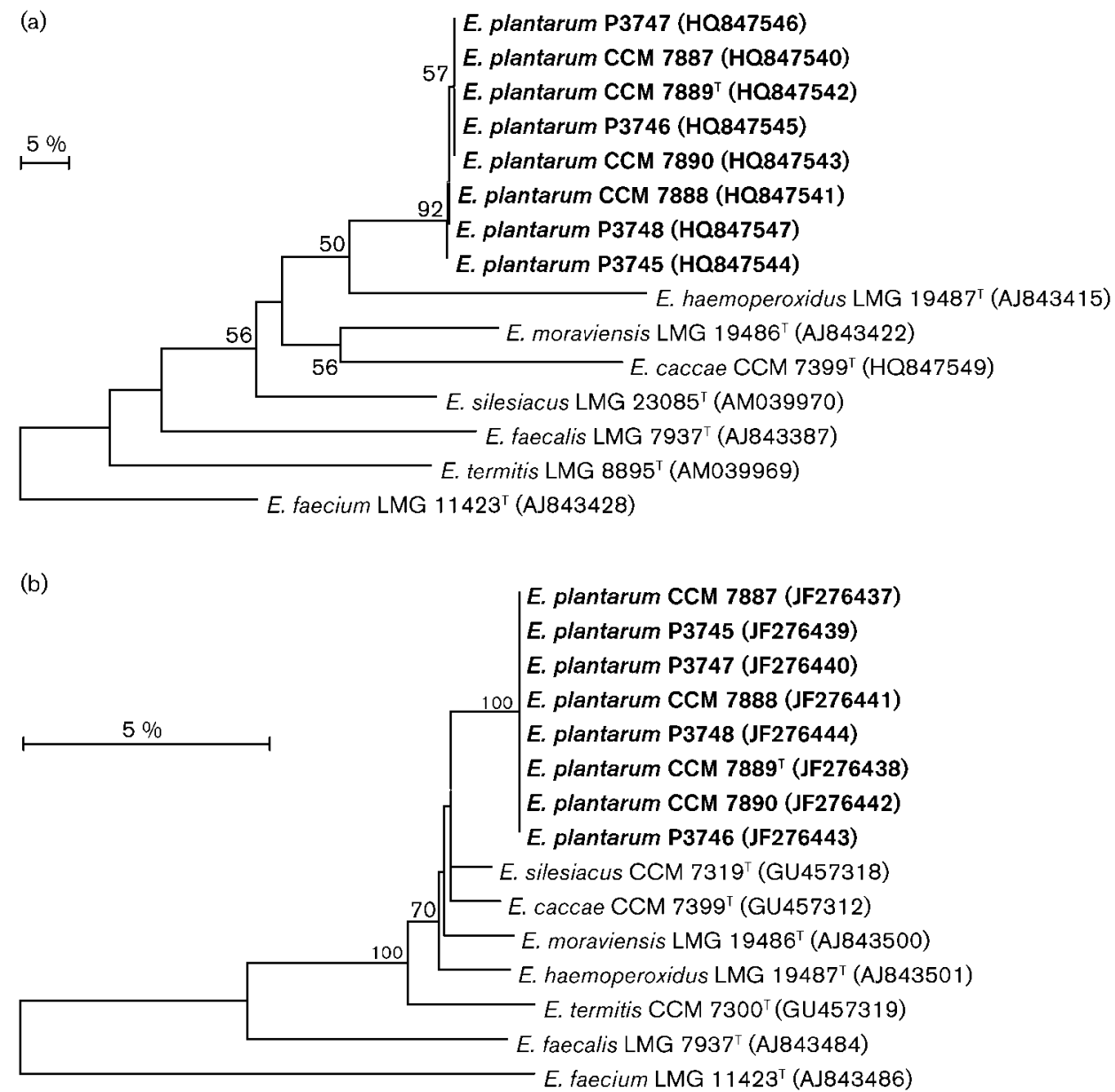

Fig. 2. Neighbour-joining phylogenetic trees based on pheS (a) and $r p o A$ (b) sequences showing the positions of Enterococcus plantarum sp. nov. within the $E$. faecalis species group. Bootstrap values ( $\geqslant 50 \%)$ based on 1000 replications are shown at branch nodes. E. faecium LMG $11423^{\top}$ was used as an outgroup. Bars, $5 \%$ sequence divergence.

et al., 2002; Merquior et al., 1994). The present study used this method to confirm the separation of the isolates from members of the E. faecalis species group. Whole-cell protein profiling was performed according to the protocol described by Pot et al. (1994). Briefly, the isolates were grown on BHI agar at $37{ }^{\circ} \mathrm{C}$ for $24 \mathrm{~h}$. Harvested cells were disrupted using a MagNA Lyser (Roche). SigmaMarker Wide Range (6.5$205 \mathrm{kDa}$; Sigma) was used as a molecular mass marker. Numerical analysis of digitized protein profiles was done using BioNumerics version 6.5. A dendrogram was constructed using Pearson's correlation similarity coefficient with the unweighted pair group method using arithmetic averages (UPGMA). All eight isolates constituted a single cluster and showed nearly identical protein profiles $(88.7 \%$ similarity), which confirmed that they represented a single species. The most similar protein profile ( $75.6 \%$ similarity) to those of the isolates was that of E. silesiacus CCM $7319^{\mathrm{T}}$. As shown in Fig. 3, the whole-cell protein fingerprinting clearly separated all eight isolates from members of the $E$. faecalis species group.
Automated ribotyping with the restriction enzyme EcoRI was performed using the RiboPrinter microbial characterization system (DuPont Qualicon) in accordance with the standard protocol for lactic acid bacteria provided by the manufacturer. Bacterial cells used for ribotyping were cultivated on BHI agar at $37{ }^{\circ} \mathrm{C}$ for $24 \mathrm{~h}$. The obtained ribopatterns were normalized and automatically categorized into ribogroups using the reference database DUP 2008 and the RiboExplorer version 2.1.4216.0 operating software (DuPont Qualicon). A dendrogram was calculated using Pearson's correlation coefficients with UPGMA using Bionumerics version 6.5. The ribopatterns were imported into the Bionumerics software using the load samples import script obtained from the manufacturer. The isolates revealed nearly identical fingerprint patterns ( $92.8 \%$ similarity) and were clearly separated from members of the E. faecalis species group. The most similar ribotype pattern $(51.8 \%$ similarity $)$ to those of the isolates was that of E. silesiacus CCM $7319^{\mathrm{T}}$. Fig. S4 shows ribotype patterns obtained from the isolates and members of the E. faecalis species group. 
Table 2. Phenotypic tests differentiating Enterococcus plantarum sp. nov. from its closest phylogenetic relatives

Species: 1, Enterococcus plantarum sp. nov.; 2, E. caccae; 3, E. faecalis; 4, E. haemoperoxidus; 5, E. moraviensis; 6, E. silesiacus; 7, E. termitis. Data were taken from this study and Švec \& Devriese (2009). +, Positive; v, variable; - , negative.

\begin{tabular}{|c|c|c|c|c|c|c|c|}
\hline Characteristic & 1 & 2 & 3 & 4 & 5 & 6 & 7 \\
\hline \multicolumn{8}{|l|}{ Production of: } \\
\hline Acetoin & + & + & + & + & + & + & - \\
\hline Arginine dihydrolase & - & - & + & + & - & + & - \\
\hline Pyrrolidonyl arylamidase & + & + & + & + & $\mathrm{V}$ & + & - \\
\hline$\beta$-Galactosidase & - & - & - & - & $\mathrm{V}$ & + & - \\
\hline Hippurate hydrolysis & + & + & + & + & + & - & - \\
\hline \multicolumn{8}{|l|}{ Production of acid from: } \\
\hline L-Arabinose & - & - & - & - & + & $\mathrm{V}$ & - \\
\hline Glycerol & - & + & + & + & + & + & + \\
\hline Lactose & - & - & + & + & + & + & + \\
\hline Melezitose & + & - & $\mathrm{V}$ & + & + & - & - \\
\hline Methyl $\alpha$-D-glucopyranoside & - & + & - & + & + & - & + \\
\hline Sucrose & + & + & + & + & + & - & - \\
\hline D-Tagatose & - & + & + & - & + & - & - \\
\hline
\end{tabular}

For the determination of DNA G $+\mathrm{C}$ content, DNA from strains P3748 and CCM $7889^{\mathrm{T}}$ was prepared according to the procedure described by Vancanneyt et al. (2001). The
$\mathrm{G}+\mathrm{C}$ content was determined by enzymically degrading the DNA into nucleosides as described by Mesbah \& Whitman (1989). The obtained nucleoside mixture was then separated by HPLC using a Waters Symmetry Shield $\mathrm{C} 8$ column at $37{ }^{\circ} \mathrm{C}$. The solvent was $0.02 \mathrm{M} \mathrm{NH}_{4} \mathrm{H}_{2} \mathrm{PO}_{4}$ $(\mathrm{pH} 4.0)$ and $1.5 \%(\mathrm{v} / \mathrm{v})$ acetonitrile. Non-methylated phage $\lambda$ DNA (Sigma) was used as the calibration reference. The DNA G + C content of strains P3748 and CCM $7889^{\mathrm{T}}$ was $36 \mathrm{~mol} \%$.

In summary, the results obtained in the present study demonstrated that the eight enterococcal isolates originating from plants represent a genotypically and phenotypically coherent taxon that can be distinguished from established enterococcal species. We therefore propose to classify them in a novel species, Enterococcus plantarum sp. nov.

\section{Description of Enterococcus plantarum sp. nov.}

Enterococcus plantarum (plan.ta'rum. L. n. planta a sprout; L. gen. pl. n. plantarum of plants).

The species description is based on eight isolates. Cells are Gram-positive, non-motile, ovoid cocci or short rods, occurring in pairs, short chains or small groups. Cocci are elongated in the direction of the chains. On Columbia agar supplemented with $5 \%$ sheep blood and on BHI agar, colonies are yellowish, smooth and circular with entire

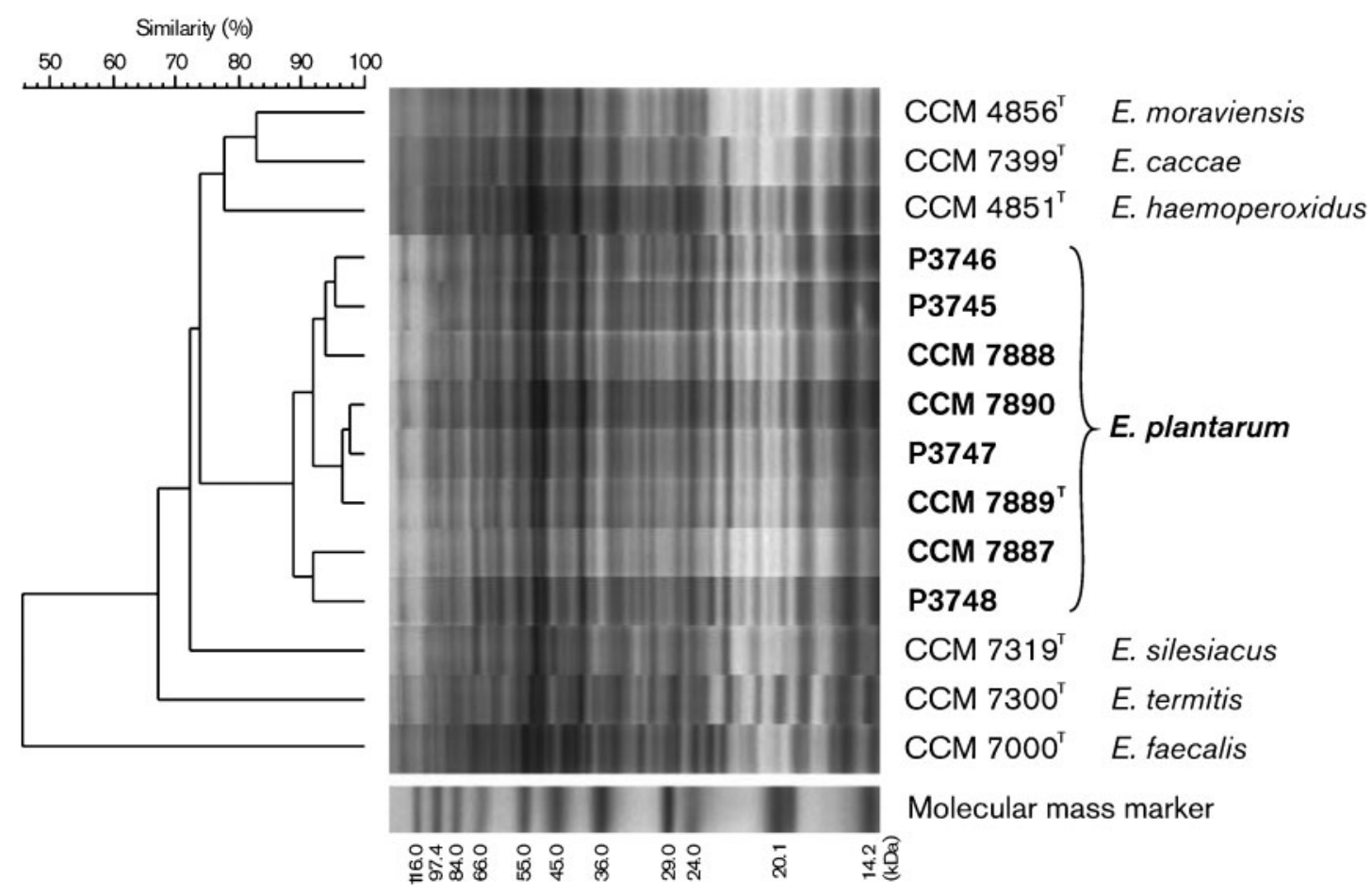

Fig. 3. Dendrogram based on whole-cell protein profiles of Enterococcus plantarum sp. nov. and members of the $E$. faecalis species group. The dendrogram was calculated using Pearson's correlation coefficients with the UPGMA clustering method ( $r$, expressed as percentage similarity values). 
margins $\left(1 \mathrm{~mm}\right.$ in diameter after cultivation at $37{ }^{\circ} \mathrm{C}$ for $24 \mathrm{~h}$ ). Grows on KAA agar with positive aesculin reaction and grows weakly on Slanetz and Bartley medium with tiny dark-red colonies. Strongly catalase-positive on blood agar; catalase-negative on blood-free media. Production of gas from glucose is negative. Grows at $10^{\circ} \mathrm{C}$ and $45^{\circ} \mathrm{C}$, at $\mathrm{pH} 9.6$ and with $6.5 \% \mathrm{NaCl}$. Group D antigen-positive. Produces acetoin (Voges-Proskauer test), leucine arylamidase, pyrrolidonyl arylamidase, urease, $\beta$-mannosidase and $\beta$-glucosidase, but not alkaline phosphatase, arginine dihydrolase, $\alpha$ - or $\beta$-galactosidase, $\beta$-glucuronidase or $\alpha$ methylglucosidase. Production of $\mathrm{N}$-acetylglucosaminidase is negative except for strain P3747. Aesculin and hippurate hydrolysis is positive. Produces acid from $\mathrm{N}$-acetylglucosamine, amygdalin, arbutin, cellobiose, $\mathrm{D}$-fructose, $\beta$-gentiobiose, D-glucose, D-mannose, melezitose, D-ribose, salicin, sucrose and trehalose, but not from D-adonitol, starch, D- or Larabinose, D- or L-arabitol, dulcitol, erythritol, D- or L-fucose, gluconate, glycerol, glycogen, inositol, inulin, 2-ketogluconate, 5-ketogluconate, lactose, D-lyxose, D-mannitol, melibiose, methyl $\alpha$-D-glucopyranoside, methyl $\alpha$-D-mannopyranoside, methyl $\beta$-D-xylopyranoside, raffinose, L-rhamnose, pullulan, D-sorbitol, L-sorbose, D-tagatose, turanose, xylitol or D- or Lxylose. Production of acid from D-galactose is negative except for strain CCM 7890. Production of acid from maltose is strain dependent (positive for strains CCM 7887, CCM $7889^{\mathrm{T}}$, CCM 7890, P3745 and P3747). With GP MicroPlates, utilizes $N$-acetyl-D-glucosamine, arbutin, cellobiose, D-fructose, $\alpha$-Dglucose, D-mannose, methyl $\beta$-D-glucoside, salicin, sucrose, trehalose, glycerol, inosine, thymidine and uridine, but not $\alpha$ or $\beta$-cyclodextrin, glycogen, inulin, mannan, Tweens 40 or 80 , $N$-acetyl- $\beta$-D-mannosamine, L-arabinose, D-arabitol, L-fucose, D-galactose, D-galacturonic acid, D-gluconic acid, $\alpha$-lactose, lactulose, maltotriose, melibiose, methyl $\alpha$-D-galactoside, methyl $\beta$-D-galactoside, 3-methyl glucose, methyl $\alpha$-D-mannoside, raffinose, L-rhamnose, sedoheptulosan, D-sorbitol, stachyose, D-tagatose, xylitol, D-xylose, acetic acid, $\alpha-, \beta$ - or $\gamma$-hydroxybutyric acid, $p$-hydroxyphenylacetic acid, $\alpha$-ketoglutaric acid, $\alpha$-ketovaleric acid, lactamide, D-lactic acid methyl ester, L-lactic acid, D- or L-malic acid, pyruvic acid methyl ester, succinic acid monomethyl ester, propionic acid, pyruvic acid, succinamic acid, succinic acid, $\mathrm{N}$-acetyl-Lglutamic acid, L-alaninamide, D- or L-alanine, L-alanyl glycine, L-asparagine, L-glutamic acid, glycyl L-glutamic acid, Lpyroglutamic acid, L-serine, putrescine, 2,3-butanediol, AMP, TMP, UMP, D-fructose 6-phosphate, $\alpha$-D-glucose 1phosphate, D-glucose 6-phosphate or DL- $\alpha$-glycerol phosphate. Table S1 gives the strain-dependent results with GP MicroPlates. The DNA G + C content of strains CCM $7889^{\mathrm{T}}$ and P3748 is $36 \mathrm{~mol} \%$.

The type strain, CCM $7889^{\mathrm{T}}\left(=\mathrm{LMG} 26214^{\mathrm{T}}=\mathrm{C} 27^{\mathrm{T}}\right)$, was isolated from flowers of Aegopodium sp.

\section{Acknowledgements}

This work was supported by the Ministry of Education, Youth and Sports of the Czech Republic (project MSM0021622416).

\section{References}

Alves, P. I., Martins, M. P., Semedo, T., Figueiredo Marques, J. J., Tenreiro, R. \& Barreto Crespo, M. T. (2004). Comparison of phenotypic and genotypic taxonomic methods for the identification of dairy enterococci. Antonie van Leeuwenhoek 85, 237-252.

Chun, J., Lee, J.-H., Jung, Y., Kim, M., Kim, S., Kim, B. K. \& Lim, Y.-W. (2007). EzTaxon: a web-based tool for the identification of prokaryotes based on $16 \mathrm{~S}$ ribosomal RNA gene sequences. Int J Syst Evol Microbiol 57, 2259-2261.

Coenye, T., Falsen, E., Vancanneyt, M., Hoste, B., Govan, J. R. W., Kersters, K. \& Vandamme, P. (1999). Classification of Alcaligenes faecalis-like isolates from the environment and human clinical samples as Ralstonia gilardii sp. nov. Int J Syst Bacteriol 49, 405-413.

Euzéby, J. P. (1997). List of Bacterial Names with Standing in Nomenclature: a folder available on the Internet. Int J Syst Bacteriol 47, 590-592.

Facklam, R. R., Carvalho, M. G. S. \& Teixeira, L. M. (2002). History, taxonomy, biochemical characteristics, and antibiotic susceptibility testing of enterococci. In The Enterococci Pathogenesis, Molecular Biology, and Antibiotic Resistance, pp. 1-54. Edited by M. S. Gilmore. Washington, DC: American Society for Microbiology.

Franz, C. M. A. P. \& Holzapfel, W. H. (2004). The genus Enterococcus: biotechnological and safety issues. In Lactic Acid Bacteria Microbiological and Functional Aspects, 3rd edn, pp. 199-247. Edited by S. Salminen, A. von Wright \& A. Ouwehand. New York: Marcel Dekker, Inc.

Huang, X. Q. \& Madan, A. (1999). CAP3: a DNA sequence assembly program. Genome Res 9, 868-877.

Hughes, M. S., James, G., Ball, N., Scally, M., Malik, R., Wigney, D. I., Martin, P., Chen, S., Mitchell, D. \& Love, D. N. (2000). Identification by $16 \mathrm{~S}$ rRNA gene analyses of a potential novel mycobacterial species as an etiological agent of canine leproid granuloma syndrome. J Clin Microbiol 38, 953-959.

Merquior, V. L. C., Peralta, J. M., Facklam, R. R. \& Teixeira, L. M. (1994). Analysis of electrophoretic whole-cell protein profiles as a tool for characterization of Enterococcus species. Curr Microbiol 28, 149-153.

Mesbah, M. \& Whitman, W. B. (1989). Measurement of deoxyguanosine/thymidine ratios in complex mixtures by high-performance liquid chromatography for determination of the mole percentage guanine + cytosine of DNA. J Chromatogr A 479, 297-306.

Müller, T., Ulrich, A., Ott, E. M. \& Müller, M. (2001). Identification of plant-associated enterococci. J Appl Microbiol 91, 268-278.

Mundt, J. O. (1961). Occurrence of enterococci: bud, blossom, and soil studies. Appl Microbiol 9, 541-544.

Mundt, J. O. (1963). Occurrence of enterococci on plants in a wild environment. Appl Microbiol 11, 141-144.

Myers, E. W. \& Miller, W. (1988). Optimal alignments in linear space. Comput Appl Biosci 4, 11-17.

Naser, S. M., Thompson, F. L., Hoste, B., Gevers, D., Dawyndt, P., Vancanneyt, M. \& Swings, J. (2005). Application of multilocus sequence analysis (MLSA) for rapid identification of Enterococcus species based on rpoA and pheS genes. Microbiology 151, 2141-2150.

Ott, E. M., Müller, T., Müller, M., Franz, C. M. A. P., Ulrich, A., Gabel, M. \& Seyfarth, W. (2001). Population dynamics and antagonistic potential of enterococci colonizing the phyllosphere of grasses. J Appl Microbiol 91, 54-66.

Pot, B., Vandamme, P. \& Kersters, K. (1994). Analysis of electrophoretic whole-organism protein fingerprints. In Modern Microbiological Methods: Chemical Methods in Prokaryotic Systematics, pp. 493-521. Edited by M. Goodfellow \& A. G. O’Donnell. Chichester, UK: Wiley. 
Saitou, N. \& Nei, M. (1987). The neighbor-joining method: a new method for reconstructing phylogenetic trees. Mol Biol Evol 4, 406425.

Sperber, W. H. \& Swan, J. (1976). Hot-loop test for the determination of carbon dioxide production from glucose by lactic acid bacteria. Appl Environ Microbiol 31, 990-991.

Švec, P. \& Devriese, L. A. (2009). Genus I. Enterococcus (ex Thiercelin and Jouhaud 1903) Schleifer and Kilpper-Bälz 1984, 32 VP. In Bergey's Manual of Systematic Bacteriology, The Firmicutes, vol. 3, pp. 594-607. Edited by P. De Vos, G. M. Garrity, D. Jones, N. R. Krieg, W. Ludwig, F. A. Rainey, K. H. Schleifer \& W. B. Whitman. New York: Springer.

Švec, P., Vancanneyt, M., Seman, M., Snauwaert, C., Lefebvre, K., Sedlácek, I. \& Swings, J. (2005). Evaluation of (GTG) $)_{5}$ PCR for identification of Enterococcus spp. FEMS Microbiol Lett 247, 59-63.

Švec, P., Nováková, D., Zácková, L., Kukletová, M. \& Sedlácek, I. (2008). Evaluation of (GTG) $)_{5}$-PCR for rapid identification of Streptococcus mutans. Antonie van Leeuwenhoek 94, 573-579.
Tamura, K., Dudley, J., Nei, M. \& Kumar, S. (2007). MEGA4: molecular evolutionary genetics analysis (MEGA) software version 4.0. Mol Biol Evol 24, 1596-1599.

Thompson, J. D., Higgins, D. G. \& Gibson, T. J. (1994). CLUSTAL W: improving the sensitivity of progressive multiple sequence alignment through sequence weighting, position-specific gap penalties and weight matrix choice. Nucleic Acids Res 22, 4673-4680.

Ulrich, A. \& Müller, T. (1998). Heterogeneity of plant-associated streptococci as characterized by phenotypic features and restriction analysis of PCR-amplified 16S rDNA. J Appl Microbiol 84, 293-303.

Vancanneyt, M., Snauwaert, C., Cleenwerck, I., Baele, M., Descheemaeker, P., Goossens, H., Pot, B., Vandamme, P., Swings, J. \& other authors (2001). Enterococcus villorum sp. nov., an enteroadherent bacterium associated with diarrhoea in piglets. Int J Syst Evol Microbiol 51, 393-400.

Vandamme, P., Pot, B., Gillis, M., de Vos, P., Kersters, K. \& Swings, J. (1996). Polyphasic taxonomy, a consensus approach to bacterial systematics. Microbiol Rev 60, 407-438. 